\title{
Migrants' rights finally front and centre of the international agenda? Exploring the perils and possibilities of the SDGs and the GCM
}

\author{
Alan Desmond* \\ Lecturer, Leicester Law School, University of Leicester, UK \\ ${ }^{*}$ Corresponding author. E-mail: alan.desmond@leicester.ac.uk
}

This Special Issue features seven papers that explore the possible consequences for the protection of migrants' rights of two important, intimately interrelated international soft-law initiatives. The first is the adoption in 2015 of the UN Sustainable Development Agenda 2030 (Agenda 2030), ${ }^{1}$ which, for the first time, saw inclusion in the global development agenda of explicit commitments on migration (Kraly and Hovy, 2020, p. 2). Agenda 2030 aims to secure inclusive growth and sustainable development and, to this end, contains seventeen Sustainable Development Goal (SDGs) and 169 related Targets, to be measured by reference to 231 unique indicators. ${ }^{2}$ The second is the adoption in 2018 of the UN Global Compact for Safe, Orderly and Regular Migration (GCM), ${ }^{3}$ which, rooted in Agenda 2030 and intended to harness migration for inclusive growth and sustainable development, was ushered in by the momentum for international action on migration generated by the 2015 refugee and migration 'crisis' in Europe (Chetail, 2019, p. 323). The GCM is informed by ten 'guiding principles' and articulates states' commitment to twenty-three objectives, accompanied by a combined total of 187 actions for the realisation of those objectives. The framework for international co-operation on migration and migrants' rights created by these twin initiatives is still in its infancy.

This Special Issue makes an important contribution to the nascent body of sustained academic analysis of the GCM and of the implications for migrants' rights of Agenda 2030. It is particularly fitting that this issue is being published in December 2020, as 18 December marks the 30th anniversary of the adoption by the UN General Assembly of the UN Migrant Workers Convention (ICRMW), ${ }^{4}$ the most comprehensive international treaty in the field of migration and human rights. A hard-law instrument containing a set of minimum-rights standards, the ICRMW and its fate is central to any understanding of the significance of the GCM and of migrants' rights protection in international human rights law. Indeed, some might question the very need to invest vast stores of international energy in elaborating the GCM given the existence of the ICRMW (Desmond, 2017, p. 3). The ICRMW and its relationship to the GCM are, accordingly, the subjects of detailed discussion in the papers by Desmond, and Grange and Majcher.

This Special Issue brings together new and established scholars, as well as key migration experts from international agencies. The contributors are uniquely qualified to provide insights into the potential impact of Agenda 2030 and the GCM on international migration law and policy, and on

\footnotetext{
${ }^{1}$ Transforming our world: the 2030 Agenda for Sustainable Development, GA (21 October 2015) UN Doc A/RES/70/1 (2015).

${ }^{2}$ 'SDG Indicators: Global indicator framework for the Sustainable Development Goals and targets of the 2030 Agenda for Sustainable Development', UN DESA, Statistics Division. Available at https://unstats.un.org/sdgs/indicators/indicators-list/. All Internet sources were accessed on 1 August 2020.

${ }^{3}$ Global Compact for Safe, Orderly and Regular Migration, GA (11 January 2019) UN Doc A/RES/73/195 (2019).

${ }^{4} \mathrm{UN}$ International Convention for the Protection of the Rights of All Migrant Workers and Members of Their Families 1990, 2220 UNTS 3.

(c) The Author(s), 2020. Published by Cambridge University Press
} 
the protection of migrants' rights. While all contributors to the Special Issue write here in a personal capacity, a number of them were closely involved in various stages of the negotiations of the GCM. Overall, the contributions are equal parts sombre and sanguine about the prospects for the SDGs and GCM to reorient international co-operation on migration towards a meaningful integration of human rights into state law, policy and practice on migration.

In the first paper, I suggest that the framework established by Agenda 2030 and the GCM for interstate co-operation on migration indexes a definitive transfer of migrants' rights protection from the realm of hard law to that of soft law. Drawing on the overlap between the GCM and the UN ICRMW, I argue that the move to an overt international-level acceptance of soft law as the primary vehicle for dealing with migrants' rights is largely consistent with states' treatment of migrants' rights in the past, but bodes ill for future rights-protection prospects. My examination of the new role for the International Organization for Migration (IOM) as co-ordinator and secretariat of the UN Network on Migration (GCM, para. 45) yields similar concerns. Despite this sombre tone, I also identify a number of key advantages of the soft-law GCM over the ICRMW, chief amongst them being the potential that the GCM holds for reframing the narrative around migration.

In the second paper, Elspeth Guild sounds a note of warning concerning the provenance of the GCM in Goal 10 of the SDGs on the reduction of inequality within and among countries, specifically its Target 7 on the facilitation of 'regular and responsible migration and mobility of people, including through the implementation of planned and well-managed migration policies'. She cautions that this may create a risk that international migration will be submerged in the 'profoundly non-legal' development framework.

Guild explores the development instruments that, along with the SDGs, are most directly relevant to the GCM and highlights the particular human rights challenges posed by the three main tools deployed to harness migration for positive development, namely brain-drain-mitigation efforts, transfer of remittances and circular migration. This development framework and set of tools may, clearly, be employed to insulate migration-control practices and the state treatment of migrants from scrutiny for compliance with international human rights law standards. Guild suggests that this danger may be headed off by effectively leveraging the human rights references and commitments contained in the development instruments in question.

Shifting the focus from the development realm to the sphere of international law, Chetail investigates the legal dimensions of the GCM. He notes that the GCM is essentially 'a political project' to develop further multilateralism and governance in the complex and sensitive field of international migration. Its resounding expression of states' commitment to respect for international law and human rights should not be underestimated at a time when 'abuses committed against migrants and violations of international law have even become an integral component' of some countries' national migration policies.

Chetail investigates the GCM's 'uneven and variegated use of international law' to achieve its numerous objectives. He highlights the several pieces of international migration law missing from the Compact and locates the document's legal relevance in, first, its restatement of some of the most basic principles of international migration law and, second, in the road it maps out for 'the progressive development of international law in a significant range of areas, including the long-neglected issue of labour migration'. While acknowledging the GCM's legal limitations, ambiguities and potential for undermining international law, Chetail heralds the drafting and adoption of the GCM as an important achievement. The alternative, he posits, was not a binding instrument, but no instrument at all.

The remaining papers are more specific in focus. Jenna Holliday, in her paper, analyses the SDGs and GCM to assess the extent to which the global development agenda takes account of the gendered dimensions of migration and puts in place a framework for advancing the protection of women migrant workers' rights. The urgency of this question cannot be contested: nearly 42 per cent of the world's international migrant workers are women (ILO, 2018), many of them undertaking risk-rich journeys from poorer countries of origin to perform work in destination states that is undervalued and unprotected in low-paid and informal sectors (Bastia and Piper, 2019). 
Holliday highlights the synergies between the existing work of UN treaty bodies and the requirements imposed by the GCM and SDGs. She conducts an analysis of the SDGs and the GCM to examine how they address the multidimensional nature of the contributions that women migrant workers make to development. Failure to adequately respond to this multidimensional nature will, she notes, restrict the role played by migration in securing positive development outcomes. Her analysis finds that, while the content of the SDGs and GCM provides potential to address the gendered dynamics of migration as it relates to women migrant workers, this potential is not being operationalised in practice. Despite the 'data revolution' in the $\mathrm{UN}^{5}$ and the calls in Agenda 2030 and the GCM for greater data to allow the elaboration of evidence-based policy, Holliday's paper highlights the wide scope for unfulfilled potential vis-à-vis data relevant for women migrants.

Holliday accordingly identifies a need to invest in the collection and analysis of multidimensional data to inform gender-responsive labour-migration governance. She also calls for a greater role for civil society in monitoring and reporting through the SDGs and the GCM. Such steps will allow a more realistic possibility of realising the global agenda's commitment to women, and to migrants more generally.

Grange and Majcher, in their paper on immigration detention, trace the evolution of multilateral processes on migration from the 1980s to the present day - a timeframe that has seen a steady and significant increase in states' use of immigration detention. By zooming in on the issue of detention, Grange and Majcher highlight how the well-developed and widely accepted binding human rights framework governing immigration detention risks being overshadowed and undermined by the nonbinding GCM, which, in its Objective 13, appears to provide strong safeguards for persons deprived of their liberty by virtue of being a non-citizen.

Grange and Majcher also make a convincing argument for the contention that, despite the UN fanfare that heralded the GCM as 'the first-ever UN global agreement on a common approach to international migration in all its dimensions', ${ }^{6}$ this epithet might be more accurately attributed to the UN ICRMW (but see Section 4 of Cholewinski's paper for the view that the GCM is considerably broader in scope than the legally binding migration-specific instruments). The authors offer trenchant criticism of the UN system itself for what they characterise as a systematic sidelining of the ICRMW that, they argue, breaches the ethical approach expected of UN programmes and operations, and contravenes the overarching principle of non-discrimination that undergirds human rights standards.

The final two papers in the Special Issue examine the contribution and influence of two important international organisations during the negotiations of the GCM. In his paper on labour migration, decent work and implementation of the GCM in the Arab states region, Cholewinski investigates ILO's role in the preparations for the adoption of the GCM. He examines selected parts of the text of the GCM, with particular reference to the ILO's mandate on decent work. The importance of focusing on decent work, both in the GCM itself and in the paper, is reflected in Cholewinski's observation of a crucial but often overlooked point: notwithstanding media headlines about the uncontrolled movements of people at the global level, much international migration today continues to be orderly and lawful, with employment at its heart.

Cholewinski explains that the ILO's concern that decent work be reflected in the GCM was motivated not only by the organisation's mandate, but also by the prominent recognition given in Agenda 2030 to the central role played by decent work in realising development. He then goes on to provide fascinating insights into the successful and failed attempts to influence the text of the GCM made by the Like-Minded Group of States on Labour Migration and Decent Work - a loose group of up to twenty-three states convened under ILO auspices - in the lead-up to the adoption of the Compact in December 2018. Cholewinski explores some of the GCM actions concerning decent work that

\footnotetext{
${ }^{5}$ See Data Revolution Group. Available at https://www.undatarevolution.org/.

${ }^{6}$ See e.g. Intergovernmental Conference on the Global Compact for Migration. Available at https://www.un.org/en/conf/ migration/global-compact-for-safe-orderly-regular-migration.shtml; and UN Refugees and Migrants: https://refugeesmigrants. un.org/migration-compact.
} 
are in tension with the interpretation of relevant human rights and labour standards, with the result that states' implementation of the GCM 'will need to be carefully reviewed with reference to their obligations under international human rights and labour law'.

In the final paper, Molnár examines the role and impact of the EU during the preparatory and inter-governmental talks leading to the adoption of the Compact. Beyond the specific focus on the GCM, Molnár's paper provides a clear overview of the EU's migration-related priorities and preoccupations. It also illustrates the challenges to advancing EU migration priorities presented by the statecentric nature of the UN and the process of formulating and maintaining a common position in an organisation comprising twenty-seven sovereign states, mixed legal competences and multiple important institutional actors.

The central question explored by Molnár is the degree to which the EU influenced GCM negotiations and their outcome. While acknowledging the inherent limitations in the indirect evidence available to assess the degree of the EU's influence on the text of the GCM adopted in December 2018, Molnár posits that the EU enjoyed considerable success in advancing the migration-related interests and priorities of the Global North, the location of key migrant destination countries. He also highlights the EU's failure to secure exclusion from the text of the GCM of issues such as 'firewalls' that decouple service provision from immigration-enforcement actions for the benefit of irregular migrants.

While each individual paper in the Special Issue stands alone and may be read independently of the other six, the papers complement and speak to each other in a variety of ways. All papers share concerns about the possible consequences of the non-binding nature of the SDGs and the GCM and what the content and structure of the Compact indicate about states' intentions for the future of international co-operation on migration and migrants' rights protection. Cholewinski, for example, strikes a note of caution concerning the relegation to the footnotes of the GCM of the three specific binding international instruments on migrant workers. This

'reflects the desire of a number of governments to downplay their relevance, in stark contrast to the more widely ratified protocols on trafficking and smuggling, which appear openly in the body of the GCM text and in respect of which there are explicit calls to promote their ratification, accession and implementation (GCM, paras 25(a), 26(a)).'

Similarly, Grange and Majcher note that, while the GCM and related documents either ignore or simply cite the ICRMW, they are 'rich in references to multiple non-binding documents and processes'.

Chetail's discussion of the omission from the Compact of the human right to leave any country, 'the most truly universal rule on migration that is binding on every UN Member State', is amplified by Guild's inquiry concerning the yoking-together of the fields of development and migration to facilitate greater discretion for states in their migration-related activities. She suggests that brain-drain-mitigation efforts, one of the three main tools for employing migration for positive development, 'presuppose that the human right to leave a country can be curtailed, possibly indefinitely'. The papers by Holliday, and Grange and Majcher indicate how the optional, voluntary and non-binding nature of the SDGs and GCM may serve to stymie human rights protections for, respectively, women migrants and migrants facing detention. In sum, the Special Issue presents a suite of mutually complementary papers that identify key risks and possibilities for migrants' rights protection. It highlights the urgent need for further inquiry into the new landscape for international co-operation on migration and for rigorous monitoring of states' compliance and implementation efforts.

Acknowledgements. This Special Issue is an outcome of a one-day seminar held in Leicester on 22 March 2019, generously funded by the Modern Law Review. I thank the speakers and all those who attended the seminar. I am also grateful for the support of colleagues at Leicester Law School, particularly Ed Bates, Peter Cumper, Sangita Lad, Holly Morton, Teresa Rowe, Cristina Saenz Perez and Katja Ziegler. I am indebted to the reviewers who facilitated the double-blind peer-review process and provided such helpful feedback on the papers featured in this Special Issue, namely Diego Acosta-Arcarazo, Idil Atak, 
Jean-Pierre Gauci, Jeff Kenner, Jan Klabbers, Magdalena Kmak, Tamás Molnár, Siobhán Mullally, Christina Oelgemöller, Antoine Pécoud, Nicola Piper, Bernard Ryan, Nando Sigona and Dan Wilsher. Finally, I wish to thank Rebecca O’Rourke of Cambridge University Press and the editors of the International Journal of Law in Context, especially Jane Holder, for their support of this Special Issue.

\section{References}

Bastia T and Piper N (2019) Women migrants in the global economy: a global overview (and regional perspectives). Gender \& Development 27, 15-30.

Chetail V (2019) International Migration Law. Oxford: Oxford University Press.

Desmond A (2017) The continuing relevance of the UN ICRMW. In Desmond A (ed.), Shining New Light on the UN Migrant Workers Convention. Pretoria: Pretoria University Law Press, 1-22.

ILO (2018) ILO Global Estimates on International Migrant Workers: Results and Methodology. Geneva: ILO.

Kraly EP and Hovy B (2020) Data and research to inform global policy: the global compact for safe, orderly and regular migration. Comparative Migration Studies 8, 1-32.

Cite this article: Desmond A (2020). Migrants' rights finally front and centre of the international agenda? Exploring the perils and possibilities of the SDGs and the GCM. International Journal of Law in Context 16, 217-221. https://doi.org/ $10.1017 /$ S 1744552320000348 